June 1990

\title{
Effective Psychotherapy with Borderline Patients
}

\author{
Edward Kim, M.D. \\ Thomas Jefferson University
}

Follow this and additional works at: https://jdc.jefferson.edu/jeffjpsychiatry

Part of the Psychiatry Commons

Let us know how access to this document benefits you

\section{Recommended Citation}

Kim, M.D., Edward (1990) "Effective Psychotherapy with Borderline Patients," Jefferson Journal of Psychiatry. Vol. 8 : Iss. 2 , Article 15.

DOI: https://doi.org/10.29046/JJP.008.2.014

Available at: https://jdc.jefferson.edu/jeffjpsychiatry/vol8/iss2/15

This Article is brought to you for free and open access by the Jefferson Digital Commons. The Jefferson Digital Commons is a service of Thomas Jefferson University's Center for Teaching and Learning (CTL). The Commons is a showcase for Jefferson books and journals, peer-reviewed scholarly publications, unique historical collections from the University archives, and teaching tools. The Jefferson Digital Commons allows researchers and interested readers anywhere in the world to learn about and keep up to date with Jefferson scholarship. This article has been accepted for inclusion in Jefferson Journal of Psychiatry by an authorized administrator of the Jefferson Digital Commons. For more information, please contact: JeffersonDigitalCommons@jefferson.edu. 


\title{
Effective Psychotherapy with Borderline Patients
}

\author{
Robert Waldinger, M.D. \\ John G. Gunderson, M.D. \\ American Psychiatric Press, 1987 \\ 227 pages \\ $\$ 27.50$
}

Edward Kim, M.D.

\begin{abstract}
"She arrived at my office the following day at the appointed hour, marched in, and announced with some fanfare: 'I am Ann.' She promptly held up her car keys, dropped them on the floor, and sat down next to them with her dress carelessly draped about her. I asked if she would like to sit on a chair, stating that I would prefer that. She shook her head and looked at the rug. Then she raised her eyes, made a squinting grimace, and took her glasses off as if to show me her eyes. She shook her head from side to side in a rather stereotyped manner and exercised her jaw, but said nothing." (p. 54)
\end{abstract}

Few clinical syndromes inspire such a combination of fascination and dread as borderline personality disorder. Irrespective of theoretical orientation or personal background, we have all (or will eventually) experienced the frustration and emotional drain of treating a borderline patient. The title, "Effective Psychotherapy Treatment with Borderline Patients" may therefore seem to be something of an oxymoron. For those desperate to find a quick technical solution to some therapeutic stalemate, this will be a disappointment as it is not a manual. Rather, it is a series of five case studies attempting to define the common aspects of "successful" dynamic psychotherapies with borderlines. Its brevity makes it easy to read quickly and reread frequently. While broaching no new theoretical groundwork, the book manages to bring some empirical wisdom to a therapeutic arena in which primitive defenses and rage can be evoked in both patient and therapist.

The authors begin with an excellent synopsis of the major psychodynamic theories of borderline personality disorder: the role of intrapsychic conflict espoused by Kernberg; the ego deficit model of Buie and Adler, and Giovacchini; and the abandonment depression model of Masterson. In discussing the technical implications of each theory, the authors focus on the question of whether or not to interpret transference or offer a supportive therapeutic stance 
early in treatment. The study examines why analytically oriented therapists working with different theoretical models achieve good results. What is the active ingredient?

The case reports are the heart of the book, eloquent and occasionally poignant in their descriptions of the chaos and struggle to achieve small victories with severely disturbed patients. One develops a definite feel for the personal style of the therapists, since each emphasizes different aspects of the therapeutic process and uses different interventions. The patients also are very different, ranging from needy and demanding to paranoid and intermittently delusional. Each report is followed by a brief discussion by Drs. Waldinger and Gunderson examining the working framework of each therapist and the personal attributes in both therapist and patient which contributed to the course of treatment. In addition, the differential diagnosis is discussed with respect to clinical presentation and DSM-III criteria. The patients were rated by the authors using a scale measuring suitability for dynamic psychotherapy, and a scale measuring suitability for dynamic psychotherapy, and a scale measuring various levels of ego functioning. The latter was used to evaluate therapeutic change over the first five years of treatment.

The final chapters attempt to draw conclusions regarding positive prognostic factors, patterns of change during treatment, and modes of therapeutic intervention. Using the rating instruments, the authors demonstrate that the patients improved globally in all areas of ego functioning, achieving a more benign and coherant sense of self and more stable object relations. Despite this encouraging conclusion, one cannot help wondering at the emotional cost of a treatment in which

“. . . both patients and therapists are usually too gratified and grateful when things work out well to do other than sigh.”' (p. 204)

The value of a book such as this rests not in its ability to transform a frustrating therapeutic process into a magical cure; rather, it provides some basic guidelines for dynamic psychotherapy with borderline patients which must be fleshed out in as excruciating detail as is presented through the case studies. After reading this book, one might not feel alone in the struggles and frustration inherent in the treatment of such patients. 